\title{
PROGRESS IN THE PROPAGATION OF SEEDLINGS OF SUGAR CANE IN LOUISIANA.
}

\author{
Hamilton P. AgEe.
}

There was presented at the 1907 meeting of the American Breeders Association, by Dr. C. O. Townsend, a paper on "The Improvement of Sugar Cane by Selecting and Breeding," which summarized in a complete manner the work of various investigators who have endeavored, since the discovery of the fertility of the seed of the cane, to propagate better varieties of this important sugar-producing plant.

A report from the Louisiana Sugar Experiment Station in 1908 told how it was long thought that this work must be confined to the Tropics, where cane seed could be secured in a fresh state for germination and be handled under the most favorable conditions of temperature. It seemed that Louisiana must depend on securing her varieties of cane from those countries where summer heat continued throughout the year; for, although the semi-tropical conditions of the southern part of that Stat are such as to permit of a profitable cane-sugar industry, nevertheless the curtailment of the growing season by the cool weather of the winter months prevents that stage of maturity which is necessary for the production of the seed-bearing arrows or tassels. This confronted Louisiana with an additional hanclicap in her competition against other cane-growing countries. Not only was an inclustry to be maintained by the growth of a tropical plant without its natural habitat, but the possibility of the propagation within her bounds of new varieties of this plant, which would thereby more likely become acclimated to her conditions, appeared to be withheld. The continuance of the sugar industry in Louisiana through its various periods of adversity may be attributed to a stroke of extreme good fortune in the introduction, as early as 1820 , while the inclustry was yet in its infancy, of a cane which by sheer chance was one of the few varieties that can be grown with profit at a latitude of $30 \mathrm{dc}$ grees north.

That cane culture in the State had grown to be a thriving inclustry by one chance in hundreds was not fully realized until after the Louisiana Sugar Experiment Station (established in 1885) had coilected from the various sugar countries throughout the world those varieties which produced the maximum returns in foreign lands noted for their large yields, and found them without exception under semi- 
tropical environments to be inferior to the cane which had been grown in Louisiana since 1820.

After the inauguration of seedling work in the Tropics, the Louisiana interests received great benefit from the introduction of the two Demerara seedlings which proved to be superior to canes then grown in the State. It was well known for a long period of years that the possibilities of securing better varieties would be considerably enhanced by germinating seed in large quantities under the prevailing conditions of the section where they were to be utilized and selecting from the great numbers the few that might prove to be superior to the varieties grown on the plantations. It was not, however, until a few years ago that the proper means of handling this delicate branch of nursery work was found. Since it was Mr. A. E. Weller who was in active charge of this undertaking, he should be recorded as being the first, and, up to the present time, the only one who has succeeded in securing the germination of sugar-cane seed at a latitude without the bounds of the Tropics. His success in this work is all the more deserving of credit since it followed a series of failures by others since 1890 .

The methods and the scheme of handling these seeds and the tender seedlings produced therefrom were described in the report, with an account of the work to that date. It only remains therefore to give information on the continuance of this endeavor to secure better varieties of cane for the Louisiana planters, and to point out the encouraging features which have presented themselves.

In preparing for the seedling work of the current year, letters were addressed to various government agricultural departments, experiment stations, botanical gardens, sugar companies, and individuals, throughout the girth of the globe, requesting cane seed for the work in hand. The writer is extremely grateful to those who contributed, for without this assistance the work would be impossible. A list of those who thus cooperated is given as follows, showing the wide range of sugar-producing countries from which the seed were secured and the different varieties of cane from which they came, and also the number of germinations secured from each variety: 


\section{Contributions of sugar-cane sccd.}

\begin{tabular}{|c|c|c|c|}
\hline Contributor. & Country. & $\begin{array}{l}\text { Varieties from which } \\
\text { sed were furnished. }\end{array}$ & $\begin{array}{l}\text { Number of seed- } \\
\text { lings secured. }\end{array}$ \\
\hline . & - & $-\quad \ldots$ & \\
\hline $\begin{array}{l}\text { Francis Wntts, Govern- } \\
\text { ment Chemint and Su- } \\
\text { perintendent of Agri- } \\
\text { culture } \ldots \ldots \ldots \ldots \ldots\end{array}$ & 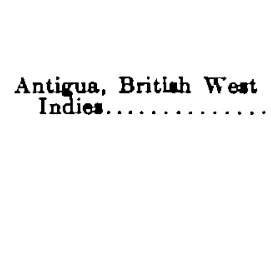 & 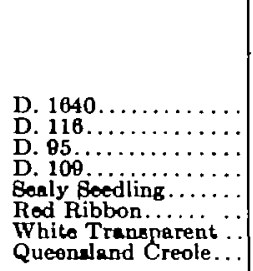 & $\begin{array}{l}\text { None } \\
\text { None } \\
\text { None } \\
\text { None } \\
\text { None } \\
\text { None } \\
\text { None } \\
\text { None }\end{array}$ \\
\hline J. C. Waldron....... & $\begin{array}{l}\text { Antiqua, British West } \\
\text { Indies................. }\end{array}$ & 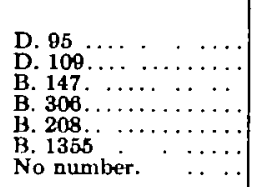 & $\begin{array}{r}5 \\
194 \\
77 \\
1 \\
\text { None } \\
2 \\
1\end{array}$ \\
\hline $\begin{array}{l}\text { Noell Deerr, Acting Di- } \\
\text { rector Sugar Experi- } \\
\text { ment Station.......... }\end{array}$ & Honolulu, Hewaii... ... & 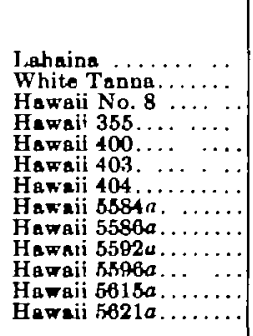 & $\begin{array}{l}\text { None } \\
\text { None } \\
\text { None } \\
\text { None } \\
\text { None } \\
\text { None } \\
\text { None } \\
\text { None } \\
\text { None } \\
\text { None } \\
\text { None } \\
2 \\
\text { None }\end{array}$ \\
\hline $\begin{array}{l}\text { D.W. May, Special Agent } \\
\text { in Charge Experiment } \\
\text { Station.............. }\end{array}$ & Mayaquex, Porto Rico & $\begin{array}{l}\text { T. } 77 \ldots \ldots \ldots \ldots \cdots \cdots \\
\text { D. } 74 \ldots \ldots \ldots \ldots\end{array}$ & $\begin{array}{l}1 \\
1\end{array}$ \\
\hline $\begin{array}{l}\text { J. T. Crawley, Director } \\
\text { Entecion Central Ag- } \\
\text { ronomica........... }\end{array}$ & $\begin{array}{l}\text { Santiago do las Voges, ,' } \\
\text { Cuba................ }\end{array}$ & 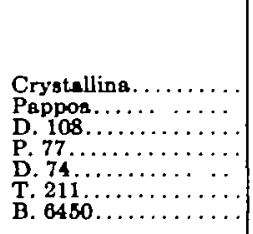 & $\begin{array}{l}\text { None } \\
\text { None } \\
\text { None } \\
\text { None } \\
\text { None } \\
\text { None } \\
\text { None }\end{array}$ \\
\hline $\begin{array}{l}\text { John R. Bovell, Buperin- } \\
\text { tendent Dopartment of } \\
\text { Agriculture............ }\end{array}$ & $\begin{array}{c}\text { Bridgetown, Barbados, } \\
\text { Britiah Weat Indies }\end{array}$ & 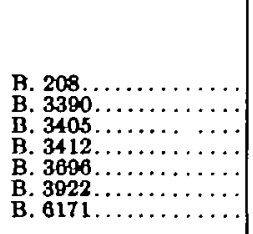 & $\begin{array}{r}3 \\
\text { None } \\
\text { None } \\
2 \\
\text { None } \\
\text { None } \\
\text { None }\end{array}$ \\
\hline $\begin{array}{l}\text { F. Evans, Acting Buper- } \\
\text { intondent Botanicsl } \\
\text { Department........... }\end{array}$ & Port-of-Rpain, Trinidad. & T. $209 \ldots \ldots \ldots \ldots$ & Nore \\
\hline
\end{tabular}

- Hybrids. 


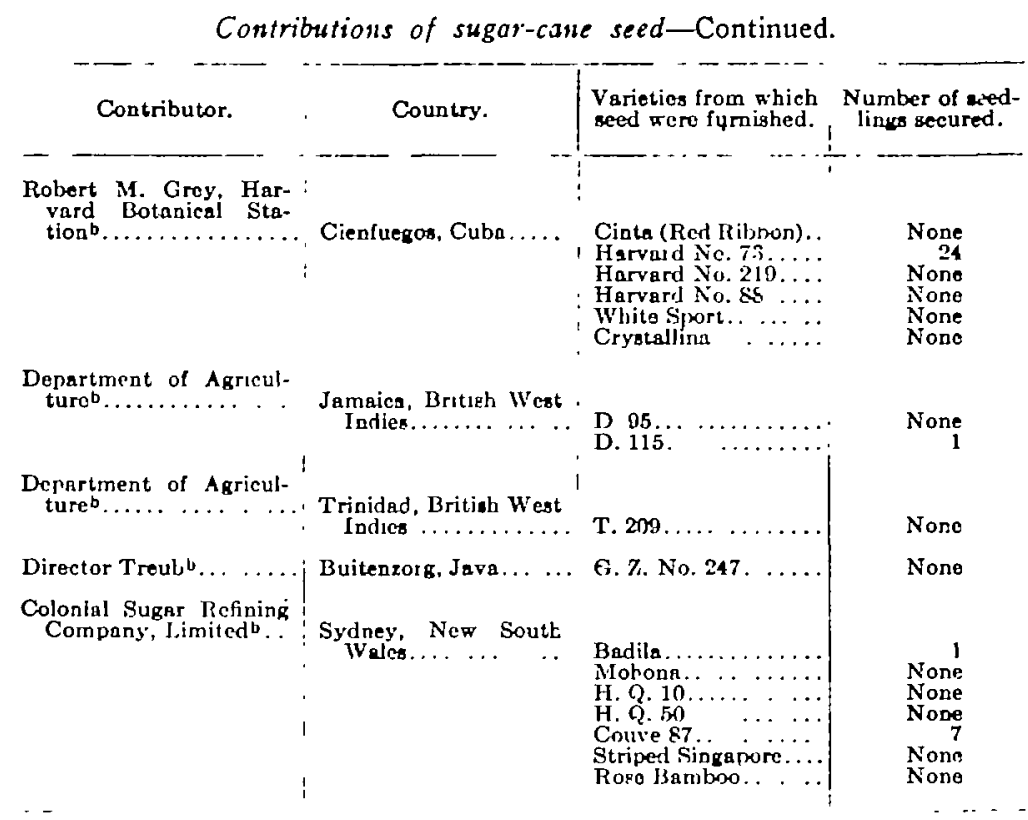

It is interesting to note the large number of germinations from the seed sent by Mr. J. C. Waldron of Antigua. This is the more remarkable because the opinion has been expressed by scientific investigators in Antigua that the cane arrows of that island do not bear fertile seed. The greater success of the Louisiana work on these seed than on those from elsewhere may be due to the fact that they were shipped in large bundles, which kept them in a better condition than those which were sent in small packages by mail. It is thought likely, however, that Mr. Waldron exercised good judgment in selecting tassels which were in prime condition for gathering.

Gratification is felt in securing eight germinations from the seed from Australia, as it is shown that the shipment of the delicate seed from such a great distance does not of necessity destroy its vitality, as has been heretofore supposed.

As was explained in the report of last year, canes obtained from each germination are classed as difierent varieties and receive a number which is prefixed by a letter indicating the country in which they originated. The entire amount is then planted out and the succeeding

- Received through Mr. David Fairohild, Aghieultural Explorer in Charge, Burrau if Plant Industry, U. S. Department of Agriculture. 
year a sufficient quantity is obtained to make a laboratory test of the juice and to plant an area large enough to furnish data the following year that will be indicative of the sugar-producing value of the juice and the tonnage yield per acre.

Unfortunately, the date of the meeting (Nov. 15, 1909) does not permit of a detailed report of the laboratory and field tests of this year, as this is at present in an incompleted stage.

The conclusions drawn from the work, so far as it has gone, give nothing of a phenomenal nature to report. However, the results are of such a satisfactory nature that promise is had that this Louisiana seedling work will ultimately prove of the greatest commercial value to the sugar interests of the State. If in the course of the next decade it is possible to originate a variety which has inherent properties that will cause it to yield a 10 per cent greater sugar return per acre than is had from the varieties now cultivated, it can be readily understood how great a money value will accrue from these investigations.

A disappointment is had in this year's results frorr the L.92, which last year gave richer juices than the celebrated D74. There are four of the new varieties-L201, L248, L450, L.511-propagated in 1908 (on which laboratory tests were made for the first time this year) that were superior in sugar content to the D74 on October 15 . Data as to tonnage may offset this advantage, and, furthermore, the canes may retrograde another year, as was the case with the L92. But, be this as it may, the results have pointed out that what once seemed possibilities of ultimate success are now closely verging upon the probable.

The value of this work will be considerably augmented by an arrangement which has been effected with the Bureau of Entomology whereby this Bureau establishes and maintains at the Sugar Experiment Station the laboratory for the investigation of insects injurious to sugar cane. These investigations are in charge of Mr. D. L. Van Dine, formerly of the Federal Experiment Station in Hawaii. Simultaneously with the study of the sugar yield and tonnage value of the varieties newly propagated by the Sugar Experiment Station, Mr. Van Dine proposes to study their insect-resisting properties so as to aid in the selection of those canes which may be fit to be disseminated throughout the State to be grown commercially.

A similar cooperation will probably be obtained from the Bureau of Plant Industry in the way of pathological investigations along the same line. 